\title{
Pengaruh Kepemimpinan Kepala Sekolah dan Konsep Diri Terhadap Kinerja Guru
}

\author{
Era Kurnia Ningsih ${ }^{1 凶}$, Happy Fitria $^{2}$, Yessi Fitriani ${ }^{3}$ \\ (1) SD Negeri 1 Kemang, Sanga Desa \\ (2) Universitas PGRI Palembang
}

$\square$ Corresponding author

(erakurnian@gmail.com)

\begin{abstract}
Abstrak
Penelitian ini bertujuan untuk mengetahui pengaruh kepemimpinan kepala sekolah dan konsep diri terhadap kinerja guru SMP/MTs Negeri dan Swasta di kecamatan Sanga Desa. Penelitian ini menggunakan metode kuantitatif dengan jenis penelitian korelasional. Populasi penelitian sebanyak 132 orang yaitu guru PNS, guru tidak tetap, dan guru honorer di SMP/MTs negeri dan swasta di Kecamatan Sanga Desa. Sampel penelitian sebanyak 99 orang. Teknik pengambilan sampel dalam penelitian ini adalah cluster sampling. Teknik pengumpulan data menggunakan kuesioner. Data analisis menggunakan teknik analisis korelasi dan regresi ganda. Hasil penelitian menunjukkan bahwa (1) kepemimpinan kepala sekolah berpengaruh signifikan terhadap kompetensi profesional guru SMP/MTs negeri dan swasta di kecamatan Sanga Desa; (2) konsep diri berpengaruh signifikan terhadap kompetensi profesional guru SMP/MTs negeri dan swasta di kecamatan Sanga Desa; dan (3) kepemimpinan kepala sekolah dan konsep diri secara bersama-sama berpengaruh signifikan terhadap kompetensi profesional guru SMP/MTs negeri dan swasta di kecamatan Sanga Desa.
\end{abstract}

Kata Kunci: Kepemimpinan kepala sekolah; konsep diri; kompetensi profesional.

\begin{abstract}
This study aimed at examining the effect of school leadership and self-concept on the performance of public and private SMP/MTs teachers in Sanga Desa sub-district. This research uses quantitative methods with correlational research type. The study population was 132 people, namely civil servant teachers, nonpermanent teachers, and honorary teachers at state and private SMP/MTs in Sanga Desa District. The research sample was 99 people. The sampling technique in this research is cluster sampling. The instruments on getting data using questionnaire. Data analysis using multiple regressions. The results showed that (1) the leadership of the principal has a significant effect on the professional competence of state and private SMP/MTs teachers in Sanga Desa sub-district; (2) self-concept has a significant effect on the professional competence of public and private SMP/MTs teachers in Sanga Desa sub-district; and (3) principal leadership and self-concept jointly affect the professional competence of state and private SMP/MTs teachers in Sanga Desa sub-district.
\end{abstract}

Keyword: Principal Leadership, Self-Concept, Professional Competence

\section{PENDAHULUAN}

Pendidikan sangat penting untuk membentuk karakter manusia, berperan dalam membentuk pribadi manusia secara normatif. Pemerintah secara intens menangani bidang pendidikan dengan harapan peningkatan sistem pendidikan dapat menghasilkan generasi penerus yang berkualitas dan kompetetif dalam masyarakat, bangsa dan negara. Abdullah (2020) menyatakan perkembangan ilmu pengetahuan dan teknologi (IPTEK) berdampak pada perubahan dan pertumbuhan ke arah yang kompleks, sehingga muncul masalah sosial dan tuntutan baru yang tidak dapat diprediksi sebelumnya, sehingga pendidikan selalu menghadapi masalah karena adanya kesenjangan antara yang diharapkan dengan hasil yang dicapai dari proses pendidikan.

Berbagai upaya yang telah dilakukan berbagai pihak untuk meningkatkan mutu pendidikan yang dilandasi kesadaran pentingnya arti pendidikan dalam peningkatan kualitas sumber daya manusia. Wujud upaya peningkatan mutu pendidikan dengan membuat undang-undang tentang pendidikan yang tercantum dalam UU No. 14 tahun 2005. Dalam pasal 1 tentang guru dan dosen menyatakan bahwa guru merupakan pendidik profesional yang memiliki tugas utama dalam mendidik, mengajar, membimbing, mengarahkan, melatih, menilai dan mengevaluasi siswa pada jalur pendidikan formal, pada jenjang pendidikan dasar dan pendidikan menengah. Sejalan pendapat Hartiwi dkk (2020) profesional guru dalam merencanakan, 
melaksanakan dan melakukan evaluasi pembelajaran di sekolah memiliki peran penting untuk menghasilkan siswa yang memiliki kualitas baik dan prestasi yang membanggakan.

Untuk menjadi guru yang profesional, seorang pendidik harus mengetahui hakikat pendidik/guru. Guru adalah seseorang yang dengan sengaja mentransfer ilmu pengetahui kepada peserta didik agar menjadi cerdas dan dewasa dalam artian memiliki kompetensi, sikap dan bijaksana. Guru merupakan unsur penting dalam proses pendidikan yang memegang tugas ganda sebagai pengajar dan pendidik. Sebagai pengajar guru harus mampu menuangkan bahan pelajaran kepada siswa, sebagai pendidik guru bertugas membimbing siswa menjadi insan yang mandiri, aktif, dan kreatif (Ivanova dkk, 2020). Renata dkk (2018) menyatakan guru yang baik harus memiliki kemampuan, merencanakan, menerapkan dan mengevaluasi serta refleksi pembelajaran untuk mewujudkan pembelajaran yang berkualitas.

Profesional yaitu orang yang menyandang suatu profesi dalam pekerjaannya, guru merupakan profesi yaitu jabatan yang memerlukan keahlian khusus yang tidak dapat dilakukan oleh semua orang di luar pendidikan (Uno, 2011). Didukung Sagala (2010) yang menyatakan bahwa profesi suatu keahlian (skill) dan kewenangan dalam suatu jabatan tertentu yang mensyaratkan kompetensi (pengetahuan, sikap dan keterampilan) tertentu secara khusus yang diperoleh dari pendidikan akademis yang intensif.

Tertuang dalam PP No. 19 Tahun 2005 pasal 28 bahwa kompetensi sebagai agen pembelajaran dalam jenjang pendidikan dasar dan menengah serta pendidikan anak usia dini terdiri atas: kompetensi pedagogik, kompetensi profesional, kompetensi kepribadian dan kompetensi sosial. Menurut Soleh dkk (2019) kompetensi profesional merupakan kemampuan penguasaan materi pembelajaran secara luas dan mendalam yang memungkinkan membimbing peserta didik memenuhi standar kompetensi yang ditetapkan dalam standar nasional pendidikan.

Kompetensi profesional guru berhubungan dengan usaha meningkatkan proses dan hasil belajar diukur dengan empat kemampuan yaitu: 1) merencanakan program belajar mengajar, 2) melaksanakan dan memimpin atau mengelola proses belajar mengajar, 3) menilai kemajuan proses belajar mengajar 4) menguasai bahan pelajaran sesuai bidang studi yang dipegang. Upaya meningkatkan kompetensi profesional guru juga sejalan dengan penelitian Khasanah dkk (2019) menunjukkan peningkatan kompetensi profesional guru melalui supervisi kepala sekolah.

Kompetensi profesional guru tidak terlepas dari peran kebijakan pimpinan, sekolah adalah organisasi yang kompleks dan unik sehingga memerlukan koordinasi yang baik. Tercapainya tujuan sekolah menunjukkan keberhasilan kepala sekolah dalam berkoordinasi dengan guru dan staf. Kualitas kepemimpinan kepala sekolah mencapai keberhasilan sekolah ditentukan sejauh mana kepala sekolah mampu untuk memimpin.

Dari segi kepemimpinan seorang kepala sekolah perlu mengadopsi gaya kepemimpinan transformasional, untuk mengoptimalkan semua fungsi yang ada di sekolah. Sebagai pemimpin kepala sekolah bertanggung jawab dalam menciptakan suasana belajar mengajar yang kondusif yang dituntut untuk dapat bekerjasama dengan guru dan staf sekolah. Kepala sekolah yang hanya berorientasi pada pengadaan sarana dan prasarana akan lemah pada pengawasan kompetensi profesional guru sehingga berimbas ketidaktercapaian penguasaan kompetensi profesional guru dan prestasi siswa.

Menurut Susanto (2016) dalam penelitiannya berjudul peran kepala sekolah dalam mengembangkan kompetensi guru di sekolah menengah negeri menyatakan bahwa proses perencanaan program pengembangan kompetensi profesional guru oleh kepala sekolah dilakukan melalui pembentukan team. Kepala sekolah juga membuat form penilaian guru terhadap proses pembelajaran di kelas, membentuk team monitoring dan evaluasi.

Apriani dkk (2020) menyatakan konsep diri positif merupakan konsep yang selalu berorientasi pada pemikiran positif, mencari peluang di setiap kesulitan dan mencari jawaban dari setiap permasalahan. Ciri seorang guru yang memiliki konsep diri positif dapat dilihat dari tampilan yang tenang jika di hadapan siswa, percaya diri, tangguh, sabar, dan memiliki keyakinan penuh bahwa ia mampu konsisten terhadap perannya sebagai pendidik yang mampu mengendalikan situasi belajar kondusif.

Konsep diri adalah pandangan seseorang tentang dirinya sendiri yang menyangkut apa yang ia ketahui dan rasakan tentang perilaku, isi pikiran dan perasaannya serta bagaimana perilakunya tersebut berpengaruh terhadap orang lain (Nugraha, 2019). Hal yang mendasari peneliti memilih menganalisis kompetensi guru dalam penelitian ini karena menurut peneliti seorang guru harus melekat dengan kompetensi. Kualitas siswa terbentuk dari kompetensi yang dimiliki guru yang mendidiknya. Untuk itu juga penting menganalisis faktorfaktor pembentuk kompetensi guru salah satunya kepemimpinan kepala sekolah dan konsep diri. Kepemimpinan kepala sekolah mempunyai peran penting dalam membentuk kinerja guru. Kepemimpinan kepala sekolah dapat diterima oleh guru jika guru memiliki konsep diri yang baik. Konsep diri sebagai faktor internal guru berupa kekuatan dasar yang memberi tenaga dan mengarahkan perilaku individu yang terdiri atas kepercayaan individu terhadap dirinya sendiri, melihat citra diri dan harga diri serta tanggapan terhadap orang lain dalam melaksanakan profesinya sebagai guru. Peningkatan kreativitas siswa dapat terbentuk jika guru memiliki konsep diri yang tinggi. Guru harus mempunyai keinginan mendorong siswa untuk lebih maju 
didukung oleh kompetensi profesional yang dimiliki guru maka guru memiliki kemampuan mengarahkan siswa menjadi unggul.

Penelitian Amalia (2019) menyatakan terdapat pengaruh signifikan konsep diri terhadap kompetensi profesional guru, dalam pembahasan menyatakan bahwa konsep diri adalah pandangan internal yang dimiliki setiap orang tentang dirinya termasuk penilaian yang bersifat pribadi mengenai berbagai karakteristik.

Konsep diri penting ada dalam diri guru, untuk mendukung guru mengendalikan situasi kelas dan pembelajaran, sehingga guru dapat secara profesional melaksanakan perannya. Kemampuan guru dalam menguasai materi dan ilmu pengetahuan harus diterapkan dalam pembelajaran dan kehidupan harus didukung konsep diri positif yang dapat mengendalikan pandangan diri terhadap hal-hal yang mengarahkan guru jadi lebih baik. Konsep diri dapat membantu guru mengembangkannya kompetensi profesionalnya pada pembelajaran dan dalam kehidupan sehari-hari secara maksimal.

Kompetensi merupakan kinerja yang rasional untuk mencapai tujuan yang dipersyaratkan sesuai dengan kondisi yang diharapkan, salah satu kompetensi yang harus dimiliki oleh seorang guru yaitu kompetensi profesional (Mulyasa, 2011). Diduung pendapat Mudlofir (2012) yang menyatakan kompetensi juga merupakan suatu sifat (karakteristik) dan orang-orang (kompeten) yang memiliki kecakapan, daya (kemampuan), otoritas (kewenangan), kemahiran (keterampilan), dan pengetahuan. Profesionalisme adalah suatu sebutan terhadap kualitas sikap para anggota suatu profesi serta derajat pengetahuan dan keahlian yang mereka mililki untuk melakukan tugas-tugasnya. Didukung pernyataan Abdullah (2020) bahwa seseorang dianggap sebagai tenaga profesional apabila dalam mengerjakan tugasnya, ia selalu berpegang teguh pada etika kerja, independen (bebas dari tekanan pihak luar), cepat (produktif), tepat (efektif), efisien dan inovatif.

Sagala (2010) menyatakan sebagai seorang profesional, guru harus memiliki kompetensi keguruan yang cukup. Kompetensi keguruan itu tampak pada kemampuannya menerapkan sejumlah konsep, asas kerja sebagai guru, mampu mendemontrasikan sejumlah strategi maupun pendekatan pengajaran yang menarik dan interaktif, disiplin, jujur dan konsisten. Mudlofir (2012) menyatakan sikap profesional merupakan motivasi instrinsik yang pada diri seseorang sebagai pendorong untuk mengembangkan dirinya menjadi tenaga profesional.

Profesionalisme merupakan suatu derajat keprofesian seorang guru dalam sikap, pengetahuan dan keahlian yang diperlukan untuk melaksanakan tugas pendidikan. Artinya kompetensi profesionalisme adalah kemampuan guru dalam bekerja dikembangkan melalui pendidikan prajabatan, dan ditingkatkan melalui pengalaman dan pendidikan (pelatihan) dalam jabatan. Kompetensi profesional merupakan unsur kemampuan penguasaan substansi pengetahuan dan keterampilan teknis sesuai dengan bidang keprofesiannya sebagai prasyarat bagi penampilan kinerjanya.

Dalam UU No. 14 tahun 2005 disebutkan kompetensi profesional adalah kemampuan guru untuk berkomunikasi dan berinteraksi secara efektif dan efisien dengan sesama guru, orang tua/wali peserta didik dan masyarakat sekitar. Hartiwi dkk (2020) menyatakan bahwa kompetensi profesional guru merupakan kemampuan yang dimiliki guru yang mencakup pengetahuan, keterampilan, dan sikap yang dibutuhkan dalam melaksanakan tugas untuk menunjang keberhasilan proses pembelajaran. Kompetensi profesional guru adalah penguasaan materi pembelajaran secara mendalam, yang mencakup penguasaan materi kurikulum mata pelajaran di sekolah dan subtansi keilmuan yang menaungi materinya, serta penguasaan terhadap struktur dan metodelogi keilmuannya.

Kompetensi profesional adalah kemampuan seorang guru dalam penugasan materi pembelajaran secara luas dan mendalam yang minimal meliputi konsep-konsep yang tercantum dalam kurikulum sekolah. Dari berbagai teori di atas dapat disimpulkan bahwa kompetensi profesional guru adalah kemampuan yang dimiliki guru dalam menguasai materi dan ilmu pengetahuan serta mampu mengembangkannya pada pembelajaran dan dalam kehidupan sehari-hari.

Gunawan (2017) menyatakan seorang yang mempunyai kemampuan untuk mempengaruhi perilaku orang lain dalam kerjanya dengan menggunakan kekuasaan. Kepemimpinan adalah suatu proses untuk mempengaruhi dan memberikan aspirasi serta mengarahkan tindakan seseorang atau kelompok untuk mencapai tujuan yang diharapkan. Kepemimpinan adalah keseluruhan aktivitas dalam rangka mempengaruhi orang-orang agar mau bekerja sama mencapai suatu tujuan yang memang diinginkan bersama selanjutnya Purwanto, (2010) kepemimpinan adalah sekumpulan dari serangkaian kemampuan dan sifat-sifat kepribadian termasuk di dalamnya kewibawaan, untuk dijadikan sebagai sarana dalam rangka meyakinkan yang dipimpinnya agar mereka mau dan dapat melaksanakan tugas-tugas yang dibebankan kepadanya dengan rela, penuh semangat, dan kegembiraan batin serta merasa tidak terpaksa. Kepemimpinanadalah suatu usaha atau kegiatan yang dilakukan seorang dalam hubungan antar manusia untuk mempengaruhi orang lain dan diarahkan melalui proses komunikasi dengan tujuan agar orang tersebut mau melakukan sesuatu dalam usaha untuk mencapai apa yang diinginkan untuk orang yang mempengaruhi atau oleh mereka semua. 
Dari definisi di atas dapat disimpulkan bahwa kepemimpinan kemampuan seseorang dalam berkoodinasi dan mengarahkan orang lain atau kelompok lain untuk mencapai tujuan yang telah ditetapkan sebelumnya. Gunawan (2017) juga mengungkapkan bahwa kepala sekolah merupakan di sekolah, kepala harus dapat memainkan perannya sebagai pemimpin untuk menggerakkan semua warga sekolah dalam rangka mencapai tujuan pendidikan pendidikan sekolah. Kepemimpinan kepala sekolah efektif sangat diperlukan untuk menopang keberhasilan pelaksanaan program sekolah yang efektif pula. Daryanto (2010: 80) kepala sekolah adalah personel sekolah yang bertanggung jawab pada seluruh aktivitas dan kegiatan sekolah juga memiliki tanggungjawab dan wewenang dalam pelaksanaan kegiatan pendidikan dalam sekolah yang dipimpinnya. Kepemimpinan kepala sekolah adalah cara kepala sekolah untuk membuat orang lain bekerja untuk mencapai tujuan sekolah.

Kepemimpinan kepala sekolah merupakan kemampuan seorang tenaga fungsional guru yang diberi tugas untuk memimpin suatu sekolah untuk menggerakkan segala sumber yang ada pada suatu sekolah sehingga dapat didayagunakan secara maksimal untuk mencapai tujuan yang telah ditetapkan. Kepemimpinan kepala sekolah adalah kemampuan pemimpin untuk membujuk dan meyakinkan bawahan sehingga mereka dengan kesungguhan dan semangat bersedia mengikuti pemimpinnya. Didukung pendapat Mulyasa (2011) yang menyatakan kepemimpinan pendidikan berkaitan dengan masalah kepala sekolah dalam meningkatkan kesempatan untuk mengadakan pertemuan secara efektif dengan para guru dalam situasi yang kondusif. Perilaku kepala sekolah harus dapat mendorong kinerja para guru, dengan menunjukkan rasa bersahabat, dekat dan penuh pertimbangan terhadap para guru, baik sebagai individu maupun sebagai kelompok.

Kepemimpinan kepala sekolah adalah kemampuan kepala sekolah dalam mendorong, membimbing, mengarahkan, dan menggerakkan para guru untuk bekerja, berperan serta guna mencapai tujuan yang telah ditetapkan. Kepemimpinan kepala sekolah adalah keseluruhan dari keterampilan dan sikap yang diperlukan oleh kepala sekolah dalam memimpin atau mengarahkan bawahan yang dipimpinnya yang merupakan kombinasi dari serangkaian perangai yang memungkinkan seseorang mampu mendorong orang lain untuk menjalankan tugas-tugas tertentu.

Dari berbagai teori di atas dapat disimpulkan kepemimpinan kepala sekolah adalah sikap efektif yang disebabkan oleh keaktifan kepala sekolah dalam menerapkan fungsinya sebagai pemimpin tertinggi di sekolah. Konsep diri adalah pandangan individu tentang dirinya sendiri menyangkut tentang apa yang dia ketahui dan rasakan tentang perilakunya, isi pikiran dan perasaaan, serta perilakunya tersebut berpengaruh terhadap orang lain. Konsep diri yang tinggi dalam diri seorang guru dapat memberikan peluang menghasilkan siswa yang kreatif. Selanjutnya Apriani dkk (2020) menyatakan kunci keberhasilan hidup adalah konsep diri positif. Konsep diri memainkan peran yang sangat besar dalam menentukan keberhasilan hidup seseorang setelah keberhasilan komunikasi, karena konsep diri dapat dianalogikan sebagai suatu operating sistem yang menjalankan komputer.

Dari berbagai teori di atas, dapat disimpulkan bahwa konsep diri guru adalah Penilaian guru terhadap diri sendiri yang bersumber dari keyakinan dan sikap positif dan negatif yang terdapat dalam dirinya.

\section{METODE PENELITIAN}

Penelitian korelasi merupakan istilah yang digunakan untuk mengukur kekuatan hubungan antar variabel. Dari data yang ada maka penelitian ini termasuk penelitian kuantitatif. Penelitian kuantitatif merupakan metode untuk menguji teori-teori tertentu dengan cara meneliti hubungan antar variabel (Noor, 2012). Variabelnya bebas adalah kepemimpinan kepala sekolah (X1) dan konsep diri (X2) dan kompetensi profesional (Y) sebagai variabel terikat (dependent variable). Penelitian ini menggunakan metode kuantitatif dengan jenis penelitian korelasional karena penelitian ini bertujuan untuk melihat hubungan antara satu variabel dengan yang lainnya. Product Moment Correlation adalah salah satu teknik untuk mencari korelasi antar dua variabel yang kerap kali digunakan dengan istilah teknik Korelasi Pearson (Sugiyono, 2015)..

\section{HASIL DAN PEMBAHASAN}

\section{Pengaruh Kepemimpinan Kepala Sekolah terhadap Kompetensi profesional Guru}

Berdasarkan hasil penelitian menunjukkan bahwa kepemimpinan kepala sekolah berpengaruh signifikan terhadap kompetensi profesional guru. Sebagai pemimpin kepala sekolah hakekatnya orang yang memahami dan menguasai manajerial dan kepemimpinan yang efektif. Kepemimpinan yang berhasil ditunjukkan dari peran kepala sekolah sebagai edukator, manajer, administrator, supervisor, leader, inovator, dan motivator. Kepemimpinan kepala sekolah yang efektif adalah kepemimpinan yang mampu memberdayakan seluruh potensi yang ada di sekolah dengan optimal sehingga guru, staf dan pegawai lain merasa ikut terlibat dalam pencapaian tujuan dan sasaran yang telah ditetapkan oleh sekolah. Hasil perhitungan hipotesis menunjukkan kepemimpinan kepala sekolah memiliki pengaruh terhadap kompetensi profesional guru hanya sebesar $21,1 \%$ sedangkan sisanya dipengaruhi variabel lain. Hasil uji hipotesis $t$ juga menunjukkan bahwa kepemimpinan kepala sekolah berpengaruh terhadap kompetensi profesional guru SMP/MTs negeri dan swasta di Sanga Desa. 
Hasil penelitian menjelaskan bahwa kepemimpinan kepala sekolah berpengaruh signifikan terhadap kompetensi profesional guru, hal ini menunjukkan bahwa kepemimpinan kepala sekolah telah melakukan perannya sebagai edukator, manajer, administrator, supervisor, leader, inovator, dan motivator. Sejalan dengan penelitian Penelitian Kartini dkk (2020) menunjukkan bahwa terdapat pengaruh positif dan signifikan kepemimpinan kepala sekolah terhadap kompetensi profesional guru. Penelitian Andriani dkk (2018) menunjukkan hasil bahwa kepemimpinan kepala berpengaruh terhadap kompetensi guru.

\section{Pengaruh Konsep Diri terhadap Kompetensi profesional Guru}

Berdasarkan hasil penelitian menunjukkan bahwa konsep diri berpengaruh terhadap kompetensi profesional guru. Hakikatnya tingkat kompetensi profesional guru dipengaruhi oleh faktor dalam diri guru itu sendiri yaitu bagaimana guru bersikap terhadap tugas yang diemban. Sikap guru terhadap pekerjaan berpengaruh terhadap tindakan guru dalam menjalankan aktivitasnya. Sikap positif dalam diri guru akan seiring dengan kemampuan guru dalan menjalankan tugasnya dengan penuh tanggung jawab sebaliknya jika guru bersikap negatif maka guru akan menjalankan tugasnya hanya sebagai rutinitas bukan tanggungjawab. Konsep diri merupakan salah satu faktor internal dalam diri guru, guru yang memiliki konsep diri yang kuat dan positif akan memandang dunia dengan cara yang berbeda dengan orang yang memiliki konsep diri yang lemah.

Hasil perhitungan hipotesis menunjukkan konsep diri memiliki pengaruh terhadap kompetensi profesional guru hanya sebesar $29,8 \%$ sedangkan sisanya dipengaruhi variabel lain. Hasil uji hipotesis t juga menunjukkan bahwa konsep diri berpengaruh terhadap kompetensi profesional guru SMP/MTs negeri dan swasta Sanga Desa, artinya menunjukkan bahwa konsep diri guru dapat meningkatkan kompetensi profesional guru di SMP/MTs negeri dan swasta di Sanga Desa.

Berdasarkan penelitian relevan di atas kesamaan hasil menunjukkan bahwa ada keterkaitan bahwa konsep diri berpengaruh pada kompetensi profesional guru, namun penelitian ini menunjukkan pengaruh yang sedang artinya konsep diri tidak dominan dapat mempengaruhi kompetensi profesional guru dikarenakan ada banyak faktor lain yang turut mempengaruhi terbentuknya kompetensi profesional guru SMP/MTs negeri dan swasta di Sanga Desa dilihat dari tingkat determinant yang yang mempengaruhi kompetensi profesional hanya sebesar $29,8 \%$.

Konsep diri tidak berperan besar terhadap kompetensi profesional guru SMP/MTs negeri dan swasta di Sanga Desa dikarenakan guru meningkatkan kompetensi profesionalnya tidak hanya melalui konsep diri, hal tersebut menunjukkan bahwa konsep diri guru belum maksimal untuk merealisir bakat dan potensi yang terpendam dalam diri, padahal jalan pikiran guru muncul dari konsep diri positif mempermudah guru dalam memahami setiap pekerjaan dalam hal ini realisasi terhadap peningkatan kompetensi profesional guru dalam bentuk pencapaian guru menguasai landasan pendidikan, menguasai bahan pengajaran, kemampuan menyusun program pengajaran dan kemampuan menyusun perangkat penilaian hasil belajar.

\section{Pengaruh Kepemimpinan Kepala Sekolah dan Konsep Diri terhadap Kompetensi profesional Guru}

Kompetensi profesional guru dapat ditingkatkan melalui kepemimpinan kepala sekolah yang baik serta didukung konsep diri positif dari dalam diri guru. Kepemimpinan kepala sekolah yang baik dapat memotivasi guru dalam menunjukkan kompetensi profesionalnya dengan meningkatkan kemampuan guru dalam menguasai landasan pendidikan, kemampuan menguasai bahan pengajaran, kemampuan menyusun program pengajaran dan kemampuan menyusun perangkat penilaian hasil belajar. Kepala sekolah harus mampu memahami, mengatasi dan memperbaiki kekurangan dan kelemahan yang terjadi di lingkungan sekolah. Pentingnya peran kepala sekolah dalam membina dan mengembangkan kemampuan guru agar guru dapat dikatakan memiliki kompetensi secara profesional. Semakin baik kepemimpinan kepala sekolah maka semakin baik pula kompetensi profesional guru.

Upaya meningkatkan kompetensi profesional guru bukanlah perkara mudah, karena guru berkualitas buka hanya dilihat dari penguasaannya terhadap teknologi tapi juga dilihat dari karakter dan mentalitasnya dalam hal ini dapat dibentuk melalui konsep diri. Peningkatan kualitas guru dapat meningkatkan kualitas pendidikan bangsa melalui pendidikan yang berkualitas maka diharapkan munculnya generasi penerus yang berkualitas. Konsep diri seorang guru sangat penting untuk memberikan gambaran terhadap diri sendiri yang berisi tentang bagaimana guru melihat dirinya sendiri sebagai pribadi yang disebut dengan pengetahuan diri, sehingga guru merasa penilaian atas dirinya dan menginginkan diri sendiri sebagai manusia yang diharapkan.

Hasil penelitian terdahulu mendukung hipotesis yang menyatakan bahwa kepemimpinan kepala sekolah dan konsep diri secara bersama-sama berpengaruh signifikan terhadap kompetensi profesional guru SMP/MTs negeri dan swasta Sanga Desa. Hubungan signifikan kepemimpinan kepala sekolah dan konsep diri merupakan hasil temuan yang menunjukkan bahwa pentingnya kepemimpinan kepala sekolah efektif dan konsep diri guru dalam melaksanakan kegiatan operasional pendidikan di sekolah. Kepala sekolah mempunyai tanggungjawab yang besar untuk melaksanakan perannya sebagai edukator, manajer, administrator, supervisor, leader, inovator dan motivator. Peran tersebut harus dapat dimplementasikan dalam kegiatan 
belajar mengajar di sekolah. Untuk mendukung peran kepala sekolah diperlukan adanya konsep diri positif dalam diri guru sebagai landasan dalam meningkatkan kualitas pendidikan melalui kompetensi profesional guru. Guru yang memiliki sikap positif terhadap pekerjaan, akan berusaha menampilkan persepsi dan kepuasan yang baik terhadap pekerjaannya dan akhirnya akan mencerminkan seorang guru yang mampu bekerja secara profesional dan memiliki kompetensi profesional yang tinggi. Implikasi temuan penelitian yang menunjukkan pengaruh signifikan kepemimpinan kepala sekolah dan konsep diri mengindikasikan bahwa semakin baik kepemimpinan kepala sekolah dan konsep diri guru dalam melaksanakan kegiatan sekolah maka dapat meningkatkan kompetensi profesional guru di SMP/MTs negeri dan swasta Sanga Desa

\section{SIMPULAN}

Kepemimpinan kepala sekolah berpengaruh signifikan terhadap kompetensi profesional guru SMP/MTs negeri dan swasta di Kecamatan Sanga Desa, artinya semakin baik kepala sekolah melaksanakan perannya sebagai pemimpin maka semakin baik pula kompetensi profesional guru. Konsep diri guru berpengaruh signifikan terhadap kompetensi profesional guru SMP/MTs negeri dan swasta di Kecamatan Sanga Desa, hal ini menunjukkan bahwa semakin positif konsep diri seorang guru maka makin baik pula penerapan pendidikan dan kualitas pendidikan sehingga guru memiliki kompetensi profesional yang tinggi. Kepemimpinan kepala sekolah dan konsep diri bersama-sama berpengaruh signifikan terhadap kompetensi profesional guru SMP/MTs negeri dan swasta di Kecamatan Sanga Desa, hal ini menunjukkan bahwa semakin adanya keterkaitan kepemimpinan kepala sekolah dan konsep diri guru dalam melaksanakan dan mengawasi kegiatan pendidikan di sekolah maka makin baik juga kompetensi profesional guru.

\section{UCAPAN TERIMA KASIH}

Terima kasih penulis ucapkan kepada kepadla sekolah dan guru SMP/MTs negeri dan swasta di Kecamatan Sanga Desa dan semua pihak yang telah membantu selesainya penelitian ini.

\section{DAFTAR PUSTAKA}

Abdullah, A. (2020). Relationship the Work Culture and Training Programs Within Performance. International Journal of Progressive Sciences and Technologies (IJPSAT), 20(1).

Andriani, S., Kesumawati, N., \& Kristiawan, M. (2018). The Influence of the Transformational Leadership and Work Motivation on Teachers Performance. International Journal of Scientific \& Technology Research, 7(7).

Amalia, D. (2019). Promoting Just Culture For Enhancing Safety Culture In Aerodrome Airside Operation. International Journal of Scientific \& Technology Research 8 (10)

Apriani, N., Fatonah, F., \& Oka, I. A. M. (2020). Rancangan Sistem Pengolahan Sertifikat Berbasis Website Sebagai Upaya Untuk Peningkatan Evaluasi Kompetensi Safety Personil Di Lingkungan PT Angkasa Pura II (Persero). Langit Biru: Jurnal IImiah Aviasi, 17-28.

Gunawan, I., \& Benty, N. (2017). Manajemen Pendidikan. Bandung: Alfabeta

Hartiwi, H., Kozlova, A. Y., \& Masitoh, F. (2020). The Effect of Certified Teachers and Principal Leadership toward Teachers' Performance. International Journal of Educational Review, 2(1), 70-88.

Ivanova, T., Gubanova, N., Shakirova, I., \& Masitoh, F. (2020). Educational technology as one of the terms for enhancing public speaking skills. Universidad y Sociedad, 12(2), 154-159.

Kartini, D., Kristiawan, M., \& Fitria, H. (2020). The Influence of Principal's Leadership, Academic Supervision, and Professional Competence toward Teachers' Performance. International Journal of Progressive Sciences and Technologies (IJPSAT), 20(1), 156-164.

Mulyasa. (2011). Menjadi Guru Profesional, Menciptakan Pembelajaran Kreatif dan Menyenangkan. Bandung, Indonesia: Remaja Rosdakarya.

Noor, J. (2012). Metodologi Penelitian. Jakarta: Prenada Media Group.

Nugraha, W. (2019) Safety Documentation: A Communication Approach For Safety Management System In Aerodrome Operator. International Journal of Scientific \& Technology Research 8 (11), 1705-1711

Peraturan Pemerintah Nomor 19 Tahun 2005

Purwanto. M. N. (2010). Administrasi dan Supervisi Pendidikan, Bandung: Remaja

Sagala, S. (2010). Supervisi Pendidikan dalam Profesi Pendidikan. Bandung: Alfabeta

Soleh, A. M., Tobari., Kesumawati, N. (2019). Development of The Practical Manual As A Learning Media For Simulator Aircraft Rescue And Fire Fighting. International Journal of Scientific \& Technology Research 8(10).

Sugiyono. (2015). Metode Penelitian Pendidikan Pendekatan Kuantitatif, Kualitatif, dan R \& D. Bandung: Alfabeta.

Susanto, A. (2016). Manajemen Peningkatan Kinerja Guru: Konsep, Strategi, dan Implementasinya. Jakarta: Prenadamedia Group.

Uno, B. H. (2011). Teori Kinerja dan Pengukurannya. Cetakan pertama. Jakarta, Indonesia: Bumi Aksara 